\title{
Development of Edu-Kit Media for Entrepreneurship Learning based on Gamification Model Toward Disruptive Education
}

\author{
https://doi.org/10.3991/ijim.v16i04.28985 \\ Heny Kusdiyanti ${ }^{(凶)}$, Karkono, Sopingi, Indra Febrianto, \\ Robby Wijaya, Nur Indah Agustina \\ Universitas Neger Malang, Malang, Indonesia \\ heny. kusdiyanti.fe@um.ac.id
}

\begin{abstract}
The current fact shows that entrepreneurship education is only a textbook without providing experimental learning to students. The current solutions have not been able to accommodate the needs of students, especially in the era of disruptive education which is developing massively. This study aims to develop gamification-based educational learning media that will be implemented in high school students to develop students' entrepreneurial spirit. This type of research is development research using the ADDIE (Analysis, Design, Development, Implementation, Evaluation) method by using a questionnaire to collect research data. After being implemented, gamification-based educational learning media succeeded in increasing student interest in entrepreneurship education as a provision for the growth of the entrepreneurial spirit in students. This learning media has also succeeded in increasing the activeness of teachers and students in the learning process that provides experimental learning to students. The collaboration between the gamification model and educational learning media is by the competency needs of students in the current era of disruptive education. Follow-up research is deemed necessary that focuses on digitizing gamification-based educational media that was developed without eliminating the activeness of teachers and students in learning.
\end{abstract}

Keywords — disruptive education, edukit, entrepreneurship learning, experimental learning, gamification

\section{Introduction}

Entering the industrial revolution 4.0 phase, the use of technology is increasingly massive, including in the world of education. There is a shift in competencies that must be possessed by students in this era. Students who will later compete with artificial intelligence must certainly improve their qualifications [1]. This condition occurs in all fields of education, especially high school education which is the last level among schools. One of the subjects at the high school level is Entrepreneurship Education, where this subject is important to create new young entrepreneurs later. The economic development of a country can be helped by the many entrepreneurs that are created. 
The number of entrepreneurs is expected not only as job seekers but also as job creators [2]. The emergence of young entrepreneurs is certainly based on the development of an entrepreneurial spirit from an early age. The formation of this entrepreneurial spirit must also be in line with current conditions. In this phase of the industrial revolution, there are five competencies, namely educational competence, competence for technology commercialization, the competence of globalization, competence in the future strategy, and counselor competence [3]. For this reason, the success of entrepreneurship education in high school is a provision to become an entrepreneur in the current era.

However, it is unfortunate that entrepreneurship education in high school is currently still in the form of a textbook. The provision of materials and assignments by teachers is no longer relevant to the current situation and developments in the business world [4]. This makes students less interested in learning entrepreneurship more deeply. Students' disinterest in entrepreneurship education is what makes it difficult to grow an entrepreneurial spirit in students. Several studies try to overcome this problem, such as research from [5]-[9] which developed simulator-based entrepreneurship education. start-up business by changing a more acceptable business idea. However, in practice, students study too much independently without any assistance from the teacher, this makes students often misconceptually that they do not understand the material in entrepreneurship education. This is of course inversely proportional to the reality in today's business world, where even professional businessmen still need a mentor to accompany them.

Departing from these conditions, [10] tries to improve it by developing a module using a product-based learning approach for entrepreneurship learning. In this study, an increase in teacher activity in learning has been carried out, but the module has not been implemented perfectly. The learning media developed are less attractive and irrelevant to the current conditions of the entrepreneurship field. This makes students bored because it only contains entrepreneurship material and is not interactive with students. Therefore, the use of appropriate learning media is considered very useful for teachers in assisting the delivery of material in the teaching and learning process [11].

In line with the results of the researchers above, other researchers [12] revealed that one of the best methods of implementing entrepreneurship education is through experience (learning by doing). This provides real experience to students about the material and problems taught by the teacher. Based on the results of the research above, the question arises of how interactive learning media and learning models can provide meaningful learning experiences so that entrepreneurial values can be instilled and formed by aspiring young entrepreneurs who are great and with integrity. The media needed is educational media which can be a vehicle for simulating starting and running a real business and can be done within the right time limit. Thus, at the end of the learning process conclusions can be drawn and the values contained in the material provided. The involvement of the companion who acts as a business mentor can also be felt by students, so that understanding of entrepreneurship material can be achieved optimally.

This article discusses strategies for increasing the entrepreneurial spirit through the development of gamification-based entrepreneurship education media. In the second part of this article, we discuss the educational media development method using the ADDIE (Analysis, Design, Development, Implementation, evaluation) method. The next section discusses the results of the development of learning media that have been tested for validity with experts and implemented at the high school level in the Malang area. 


\section{Methods}

\subsection{Research design}

This research is a type of development research that uses the ADDIE (Analysis, Design, Development, Implementation, evaluation) method. This method was chosen because it is following the objectives of the research to develop and test the effectiveness of the developed learning media. The stages in the ADDIE method used to refer to [13] are as follows;

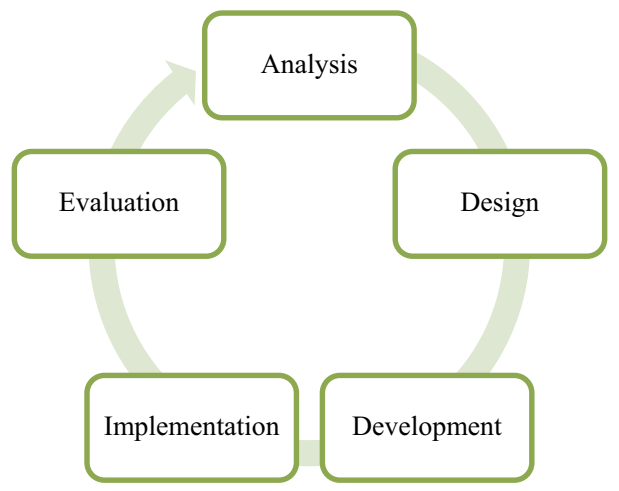

Fig. 1. Research design

Regarding to the Figure 1 above, it can be seen that the first stage is Analysis where the researcher determines the problem to be solved in the research. The problem found is the ineffectiveness of entrepreneurship education in fostering the entrepreneurial spirit of students. This is because there are no relevant learning media to accommodate students' needs following current conditions. The second stage is Design which produces the design of the educational media that will be developed. In this stage, an educational media design is created in the form of an economic monopoly consisting of several components including opportunity cards, spending cards, play money, financial forms, buying and selling forms, and business-type banners. The results of this design will be realized in the next stage.

The next stage is Development where in this stage all the designs that have been prepared previously are realized in the form of real products to be ready for implementation. In this development stage, media validity tests were also carried out with material experts and media experts aimed at preparing the developed media to be feasible to be implemented in the field. After experiencing the revision of the expert validation, the implementation stages were carried out which were applied to high school students in the Malang area. In this implementation stage, the researcher becomes a facilitator who helps students to play economic monopoly in a business simulation. The researcher as a facilitator provides instructions at the beginning about the rules and how to play the developed educational media. The last stage is the evaluation obtained from the results of filling out the questionnaire given to students. This evaluation stage aims to determine student acceptance of the developed media and the success of this media to foster the entrepreneurial spirit of students. 


\subsection{Samples and data collection techniques}

In this study, a sample of high school students in the Malang area was used to be the subject of the implementation of the developed media. The high schools are Al-Rifaie Modern High School and Cendika Bangsa High School, each of which consists of 20 students. Data collection techniques were carried out using questionnaires distributed to media and material experts and students as research respondents. There are two different questionnaires, where the first questionnaire aims to determine the validity of the learning media validated by material and media experts. While the second questionnaire aims to determine the acceptance of media for students and the level of success in growing students' entrepreneurial spirit.

\section{$3 \quad$ Result and discussion}

This section describes the findings and discussion of the research conducted following the objectives of the previous research. This section describes the description of the learning media developed and the results of the validation to the implementation of the learning media as well as the researcher's study of the findings.

\subsection{Description of gamification-based educational learning media}

The educational learning media developed is an economic monopoly that consists of several components including 1) business banners, 2) opportunity cards, 3) spending cards, 4) play money, 5) financial forms, 6) buying and selling forms. The money replica and business banner as a important components of this learning media can be seen in the Figure 2. These components are assembled into a monopoly unit which is carried out using the gamification method. This gamification method is applied to provide contextual learning and experimental learning to high school students in entrepreneurship education. With these two learning experiences, it is hoped that later high school students will grow an entrepreneurial spirit and want to explore entrepreneurship education at the next level. In this edukit learning media, students are the main actors and entrepreneurship teachers who will later act as facilitators during the learning process. These facilitators replace mentors in the real business world. 

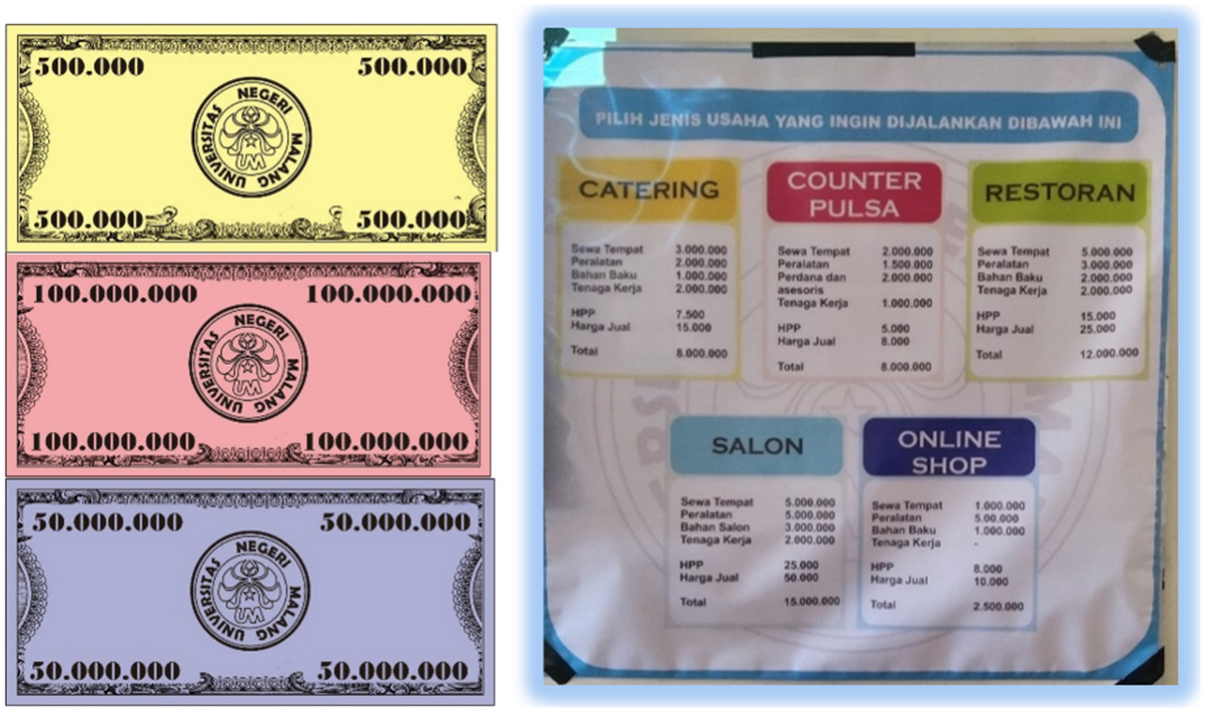

Fig. 2. (a) Money replica, (b) Business banner

In line with the large contribution of Micro, Small, and Medium Enterprises (MSMEs) in Indonesia, entrepreneurship learning needs to be carried out effectively and efficiently to foster the entrepreneurial spirit of students who will later become young entrepreneurs in the industrial world. Entrepreneurship learning is not only about being a seller or marketing but also includes being a creator and innovator [8]. This paradigm is often wrong among people until now. Many people experience misunderstandings about the meaning of entrepreneurship learning itself. This has resulted in the wrong implementation of entrepreneurship learning that has been carried out so far. Entrepreneurship learning in schools often focuses on how to sell or market products without a strategy to determine potential product choices in the market. This need is accommodated in this gamification-based educational media. In the business simulation process using an economic monopoly, students are not only taught to sell goods but are also taught to set up business establishment strategies to manage business money. Creativity and innovation possessed by high school students can collaborate with an entrepreneurial spirit which will later produce innovative products and increase the income of the surrounding community [6], [14]-[17]. The success of entrepreneurship learning is expected by various groups, especially practitioners of entrepreneurship education.

Implementation of entrepreneurship education can be done flexibly. This is in line with the industrial revolution 4.0 that has occurred in Indonesia where technology has become the basis of everyday human life [18]. In line with this development, of course, entrepreneurship education needs to be carried out more effectively and efficiently. The use of technology and conformity to student characteristics is important for teachers to do in this learning. There are various kinds of media that teachers can use in the learning process [19]. This allows teachers to use a variety of existing learning media to support the learning carried out. If we look further, the implementation of this learning media 
must also be supported by the right method. One model that provides direct learning experiences to students is the gamification model [20]. The collaboration between the gamification method and the edukit learning media is an appropriate learning unit in fostering the entrepreneurial spirit of students.

The advantages of this edukit learning media are (1) user-friendliness, which makes it easier for students to simulate the process of running a real business and is assisted by a facilitator as a business mentor; (2) responsive, which can easily adapt to the real conditions that exist in the real business world. This situation is accommodated from the existence of opportunity cards, and spending cards that are following current conditions; (3) accountable, who can find out the results of the evaluation that has been carried out after completing the learning. In addition, users will also easily find out the feedback given by each other user through the applied gamification method. (4) transparent, which allows every businessman (student group) to know the progress of other businesses to increase their business capacity or establish cooperation with each other; (5) trusted, namely providing a trusted phenomenon that exists in today's business world. This media has also been validated by material and media experts to test its validity. The existence of these advantages will later be developed as educational media that is expected to provide real learning experiences and successfully foster an entrepreneurial spirit in students. This is following what is stated by [21], [22] that learning media are everything that is conditioned to increase knowledge, change attitudes, or increase the skills of anyone who uses it.

The collaboration between the gamification model and educational learning media in entrepreneurship education cannot be separated from the learning objectives which are also in line with the current industrial revolution 4.0. In the era of the Industrial Revolution 4.0, not only teachers must improve their teaching competencies, but also shift student competencies to 4C, namely: (1) Communication, (2) Critical Thinking and Problem Solving, (3) Collaboration, (4) Creativity and imagination. These competencies are needed by students in the 21 st century which have also witnessed the industrial revolution 4.0 [23]-[26]. This competency is very relevant to the needs in the entrepreneurial world where the teacher becomes a facilitator during media-based learning [27]. This is following the values in entrepreneurship including creativity and innovation [28]-[30]. The achievement of 4C competencies in entrepreneurship education at the high school level is the beginning of the birth of young entrepreneurs with the various innovative products they create.

\subsection{Implementation result of edukit learning media}

The developed media has been implemented in two high schools in Malang, namely Al-Rifaie Modern High School and Cendika Bangsa High School with 20 students each. Before and after the process of implementing the media, students were given a questionnaire aimed at knowing the results of the implementation of this media. Two indicators are measured in this implementation, namely student interest in entrepreneurship education and the level of activeness of teachers and students in learning. The following are the results of the implementation of learning media in indicators of student interest in entrepreneurship education. This increase in student interest in 
entrepreneurship education can be seen from the results of filling out the questionnaire where at the time of the pre-trial, only $65.40 \%$ were interested in entrepreneurship education. After the application of this media, student interest increased to $89.90 \%$. The results of the increase are shown in the table below:

Table 1. Increment of student interest in entrepreneurship education

\begin{tabular}{|l|c|c|}
\hline \multicolumn{1}{|c|}{ Action } & Percentage & Increment \\
\hline Pre-Implementation & $65.40 \%$ & $24.50 \%$ \\
Media Implementation & $89.90 \%$ & \\
\hline
\end{tabular}

Source: Processed by researchers, 2021.

Regarding to Table 1 show that the application of gamification-based educational media has been able to increase student interest in entrepreneurship education which is quite significant, namely by $24.50 \%$. With a very good category. The percentage increase in student interest can be seen in the following graph;

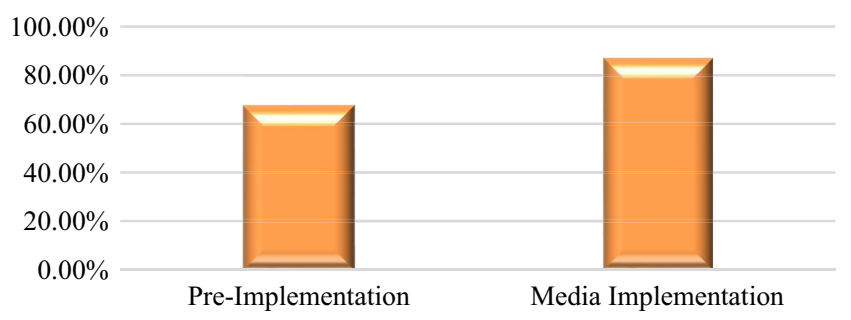

Fig. 3. Increment of student interest

Source: Processed by researchers, 2021.

The implementation of gamification-based educational learning media carried out in the era of the industrial revolution 4.0 is not only focused on achieving student competence in the current era but also refers to their competence in their role in the community. In addition to the $4 \mathrm{C}$ competencies that must be possessed, students must also have Social Skills which are one of the main demands in this 4.0 industrial revolution [31]-[33]. Several competencies must be possessed in Social Skills, including coordinating with others and service orientation.

Based on these competencies, social skills are one of the cross-functional skills that must be possessed in the 4.0 industrial revolution that is happening today. If it is associated with entrepreneurship, there is a branch of entrepreneurship that also leads to this competence, namely social entrepreneurship. Social Entrepreneurship is entrepreneurship that carries out business activities not only based on profit but also considering the social impacts it causes [34]. When viewed further, this also makes a significant contribution to supporting the welfare of the community, especially in the periphery [35]-[37]. The achievement of social skills in entrepreneurship learning absolutely must be fulfilled by every student. In addition to providing benefits for the students themselves, this learning will also provide considerable benefits for the surrounding community. The collaboration of social entrepreneurship models carried out in learning 
will form young entrepreneurs who are not only based on business profits, but also on the benefits of the business being run. This is the reason the collaboration of gamification models and educational media is important to be implemented since high school education level.

The results of increasing student interest are also inseparable from the activities of teachers and students. Before the implementation of this gamification-based educational media, teacher activity was not too high, namely $64.17 \%$, while student learning activity was relatively low, namely $49.93 \%$. The activities of teachers and students also increased after being explained by the researcher and carrying out learning following the previously planned Learning Device Design (RPP). student and teacher learning activities starting at the pre-test and media trials are presented in the table as follows the table.

Table 2. Increment of teacher and student activities

\begin{tabular}{|l|c|c|}
\hline \multicolumn{1}{|c|}{ Action } & Teacher Activiry & Student Activity \\
\hline Pre-Implementation & $64.17 \%$ & $49.93 \%$ \\
Media Implementation & $89.28 \%$ & $92.23 \%$ \\
\hline
\end{tabular}

Source: Processed by researchers, 2021.

Regarding to Table 2 show that the application of gamification-based educational learning media can increase teacher activities and also student learning activities during the entrepreneurial learning process. Teacher activity increased by $25.11 \%$ from pretrial to media trial with the criteria of "very good". As for the increase in student activity by $42.30 \%$ from pre-trial to media trials with the criteria of "very good". The increase in teacher and student activity is presented in the following graph:

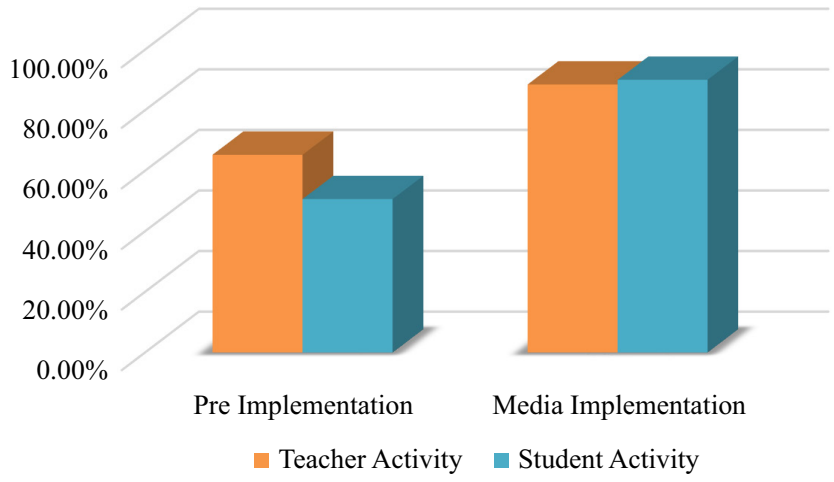

Fig. 4. Increment of teacher and student activities Source: Processed by researchers, 2021.

Various kinds of learning models can be applied in entrepreneurship education. One suitable learning model is the gamification model [4], [20]. The application of this learning model will provide a contextual experience for students to carry out business simulation activities directly. Students will carry out direct activities in conducting 
business activities, which will also hone students' critical thinking during entrepreneurship learning. Learning through the gamification model is one of the efforts that can be made to prepare quality human resources in the face of the industrial revolution 4.0 [6], [20], [38]. The achievement of this competency will also support the success of entrepreneurship learning which is carried out to foster the entrepreneurial spirit of students.

Game-based learning implemented in entrepreneurship learning was not new in the world of education. Many researchers have also discussed the implementation of this learning model [6], [20], [39], [40]. In this study, the success of the application of the gamification model in entrepreneurial learning has been tested. If viewed further, this learning will not only improve students' critical thinking but will also provide several different experiences to students including 1) learning by doing, 2) reflective learning, 3) situated learning, and 4) learning from crises [40].

Some of these learning experiences become one of the supports that will provide a fairly large contribution to the success of entrepreneurship education in fostering the entrepreneurial spirit of students which is implemented through the gamification model. The important thing that must also be considered in this entrepreneurship education is the game scenario used. Teachers can easily arrange game scenarios that will be applied during learning but must be following the final goal to be achieved.

Based on the explanation above, it can be concluded that the educational learning media implemented with the gamification method succeeded in increasing student interest in entrepreneurship education which was the initial provision to grow the entrepreneurial spirit in students. In addition, this educational media has also succeeded in increasing the activities of teachers and students during the entrepreneurship learning process which is useful in supporting the success of entrepreneurship learning.

\section{Conclusion}

Based on the explanation above, it can be concluded that the educational learning media that has been developed has succeeded in increasing student interest in entrepreneurship education which is the initial provision for the growth of the entrepreneurial spirit in students. This media is also successful in increasing the activeness of teachers and students during the learning process which provides contextual learning experiences to students. The implementation of edukit learning media is important considering the large contribution of MSMEs to Indonesia's economic growth. The existence of learning media that can improve the entrepreneurial spirit of students will later form innovative and creative young entrepreneurs. The developed learning media collaborates with a gamification model that is following the current conditions of the 4.0 industrial revolution which requires students not only to have $4 \mathrm{C}$ competencies but also several other competencies that are in line with the 4.0 industrial revolution. Based on the results and discussion in this study, it is deemed necessary to conduct follow-up research as an optimization of the results obtained in this study. This follow-up research is expected to focus on digitizing the educational media that was developed without eliminating the elements of activity and participation for teachers and students in the learning process. 


\section{$5 \quad$ Acknowledgment}

This study was supported by the Research Grants from Institute for Research and Community Service (LP2M) Universitas Negeri Malang. The authors are responsible for any unintended errors.

\section{References}

[1] Y. Yeo and J. D. Lee, "Revitalizing the Race Between Technology and Education: Investigating the Growth Strategy for the Knowledge-based Economy Based on a CGE Analysis," Technol. Soc., vol. 62, p. 101295, 2020, https://doi.org/10.1016/j.techsoc.2020.101295

[2] H. Kusdiyanti, I. Febrianto, and R. Wijaya, "Enchancing Teacher Competitiveness of Entrepreneurship Through Augmented Reality Module: Steam Approach,” Int. J. Sci. Technol. Res., vol. 8, no. 12, pp. 3373-3381, 2019.

[3] I. Febrianto and R. Inayati, "Will the Future Economics Teacher Be Prepared to Be up against Industrial Revolution 4.0?” KnE Soc. Sci., vol. 2020, pp. 1034-1046, 2020, https:// doi.org/10.18502/kss.v4i6.6660

[4] K. Fellnhofer, "Game-based Entrepreneurship Education: Impact on Attitudes, Behaviours and Intentions," vol. 3, no. July, 2018, https://doi.org/10.1504/WREMSD.2018.089066

[5] I. Y. Basri, D. Faiza, M. Nasir, and N. Nasrun, "Implementasi Pembelajaran Berbasis Produk Dalam Rangka Menyiapkan Lulusan SMK Menjadi Wirausahawan Muda," INVOTEK J. Inov. Vokasional dan Teknol., vol. 19, no. 1, pp. 43-52, 2019, https://doi.org/10.24036/ invotek.v19i1.433

[6] J. C. Huizenga, G. T. M. ten Dam, J. M. Voogt, and W. F. Admiraal, "Teacher Perceptions of the Value of Game-based Learning in Secondary Education," Comput. Educ., vol. 110, pp. 105-115, 2017, https://doi.org/10.1016/j.compedu.2017.03.008

[7] C. Nalyanya, B. Ndemo, and J. Gathungu, "Doctoral Student, School of Business," 2015.

[8] T. Nurseto, "Pendidikan Berbasis Entrepreneur," J. Pendidik. Akunt. Indones., vol. 1, no. 4, p. 53, 2010 [Online]. https://doi.org/10.21831/jpai.v8i2.954

[9] A. Omri and S. Dhahri, "Entrepreneurship Contribution to the Three Pillars of Sustainable Development: What Does the Evidence Really Say?” 2018.

[10] F. Cosenz and G. Noto, "Turning a Business Idea Into a Real Business Through an Entrepreneurial Learning Approach Based on Dynamic Start-up Business Model Simulators," 2017. Accessed: Jan. 22, 2020 [Online]. Available: https://www.researchgate.net/ publication/317037752

[11] A. Yulastri, H. Hidayat, S. Islami, and F. Edya, "Developing an Entrepreneurship Module by Using Product-Based Learning Approach in Vocational Education,” Int. J. Environ. Sci. Educ., vol. 12, no. 5, pp. 1097-1109, 2017.

[12] L. A. Zampetakis, K. Kafetsios, M. Lerakis, and V. S. Moustakis, "An Emotional Experience of Entrepreneurship: Self-Construal, Emotion Regulation, and Expressions to Anticipatory Emotions," J. Career Dev., vol. 44, no. 2, pp. 144-158, 2017, https://doi. org/10.1177/0894845316640898

[13] R. M. Branch, Instructional Design: The ADDIE Approach. New York: Springer, 2010. https://doi.org/10.1007/978-0-387-09506-6

[14] D. J. Teece, "Business Models, Business Strategy and Innovation," Long Range Plann., vol. 43, 2010, https://doi.org/10.1016/j.lrp.2009.07.003

[15] A. A. Syuhada and W. Gambett, "Online Marketplace for Indonesian Micro Small and Medium Enterprises based on Social Media," Procedia Technol., vol. 11, pp. 446-454, Jan. 2013, https://doi.org/10.1016/j.protcy.2013.12.214 
[16] S. Gallagher and G. Garrett, "Disruptive Education: Technology-Enabled Universities," no. July, 2013 [Online]. Available: http://ussc.edu.au/ussc/assets/media/docs/publications/130801 DisruptiveEducation GallagherGarrett.pdf

[17] D. Lase, "Pendidikan di Era Revolusi Industri 4.0," SUNDERMANN J. Ilm. Teol. Pendidik. Sains Hum. dan Kebud., vol. 1, no. 1, pp. 28-43, 2019, https://doi.org/10.36588/sunder$\underline{\text { mann.vli1.18 }}$

[18] T. Huseno, "Strategi Perguruan Tinggi dalam Upaya Meningkatkan Kualitas Sumberdaya Manusia," Maj. Ilm. Lontar, vol. 24, no. 2, pp. 27-36, 2018.

[19] L. W. Mina, “Analyzing and Theorizing Writing Teachers' Approaches to Using New Media Technologies," Comput. Compos., vol. 52, pp. 1-16, 2019, https://doi.org/10.1016/j. compcom.2019.01.002

[20] J. Hamari, D. J. Shernoff, E. Rowe, B. Coller, J. Asbell-Clarke, and T. Edwards, “Challenging Games Help Students Learn: an Empirical Study on Engagement, Flow and Immersion in Game-based Learning," Comput. Human Behav., vol. 54, pp. 170-179, 2016, https://doi. org/10.1016/j.chb.2015.07.045

[21] S. Ramoglou and E. W. K. Tsang, "A Realist Perspective of Entrepreneurship: Opportunities as Propensities," Q Acad. Manag. Rev., vol. 41, no. 3, pp. 410-434, 2016, https://doi. org/10.5465/amr.2014.0281

[22] S. Ramoglou, Stelios, and C. Zyglidopoulos, "The Constructivist View of Entrepreneurial Opportunities: a Critical Analysis," Small Bus. Econ., 2014, https://doi.org/10.1007/ s11187-014-9590-4

[23] F. Guzmán-Simón, E. García-Jiménez, and I. López-Cobo, "Undergraduate Students' Perspectives on Digital Competence and Academic Literacy in a Spanish University," Comput. Human Behav., vol. 74, pp. 196-204, 2017, https://doi.org/10.1016/j.chb.2017.04.040

[24] R. Wulansari, H. Rusnayati, D. Saepuzaman, S. Karim, and S. A. Feranie, "The Influence of Scientific Creativity and Critical Worksheets (SCCW) on Creative Thinking Skills and Critical Scientific as Well as Students' Cognitive Abilities on Project-based Learning Work and Energy Concepts,” J. Phys. Conf. Ser., vol. 1280, no. 5, 2019, https://doi. org/10.1088/1742-6596/1280/5/052039

[25] H. Subekt, M. Taufiq, H. Susilo, I. Ibrohim, and H. Suwono, "Mengembangkan Literasi Informasi Melalui Belajar Berbasis Kehidupan Terintegrasi Stem Untuk Menyiapkan Calon Guru Sains Dalam Menghadapi Era Revolusi Industri 4.0: Revieu Literatur,” Educ. Hum. Dev. J., vol. 3, no. 1, pp. 81-90, 2017, https://doi.org/10.33086/ehdj.v3i1.90

[26] A. Hidayatno, A. R. Destyanto, and C. A. Hulu, "Industry 4.0 Technology Implementation Impact to Industrial Sustainable Energy in Indonesia: a Model Conceptualization,” Energy Procedia, vol. 156, pp. 227-233, 2019, https://doi.org/10.1016/j.egypro.2018.11.133

[27] H. Muhonen, A. von Suchodoletz, E. Doering, and J. Kärtner, "Facilitators, Teachers, Observers, and Play Partners: Exploring How Mothers Describe Their Role in Play Activities Across Three Communities," Learn. Cult. Soc. Interact., vol. 21, no. March, pp. 223233, 2019, https://doi.org/10.1016/j.lcsi.2019.04.002

[28] W. T. Subroto, "Menanamkan Nilai-Nilai Entrepreneurship Melalui Pendidikan Ekonomi Pada Era Masyarakat Ekonomi Asean,” J. Econ., vol. 11, no. 1, p. 16, 2015, https://doi. org/10.21831/economia.v11i1.7751

[29] Y. K. Kheng, "The Inculcation of Critical Reflection through Reflective Learning Log: An Action Research in Entrepreneurship Module,” Int. Educ. Stud., vol. 10, no. 12, p. 153, 2017, https://doi.org/10.5539/ies.v10n12p153

[30] M. Flavin, "Disruptive Technologies in Higher Education,” Res. Learn. Technol., vol. 20, no. SUPPL, pp. 102-111, 2012, https://doi.org/10.3402/rlt.v20i0.19184

[31] K. Schwab, "The Fourth Industrial Revolution," 2016 [Online]. Available: http://www. weforum.org 
[32] K. Schwab and R. Samans, "Global Challenge Insight Report: The Future of Jobs," World Econ. Forum, no. January, pp. 1-167, 2016, https://doi.org/10.1177/1946756712473437

[33] S. Mkwanazi and C. Mbohwa, "Implications of the 4 th Industrial Revolution on Entrepreneurship Education," 2018.

[34] M. A. Boulven et al., "Model of Islamic Social Entrepreneurship: A Study on Successful Muslim Social Entrepreneur in Malaysia," MATEC Web Conf., vol. 150, pp. 10-13, 2018, https://doi.org/10.1051/matecconf/201815005093

[35] J. Kurowska-Pysz, "Opportunities for Cross-border Entrepreneurship Development in a Cluster Model Exemplified by the Polish-czech Border Region," Sustain., vol. 8, no. 3, 2016, https://doi.org/10.3390/su8030230

[36] R. R. Pathak, B. R. Poudel, and P. E. Acharya, "Social Enterprise and Social Entrepreneurship: Conceptual Clarity and Implication in Nepalese Context," NCC J., vol. 3, no. 1, pp. 143-152, 2018, https://doi.org/10.3126/nccj.v3i1.20256

[37] J. C. Short, T. W. Moss, and G. T. Lumpkin, "Research in Social Entrepreneurship: Past Contributions and Future Opportunities,” Strateg. Entrep. J. Strat. Entrep. J., vol. 3, pp. 161-194, 2009, https://doi.org/10.1002/sej.69

[38] E. Sitinjak, B. Meidityawati, R. Ichwan, N. Onggosandojo, and P. Aryani, "Enhancing Urban Resilience through Technology and Social Media: Case Study of Urban Jakarta," Procedia Eng., vol. 212, no. 2017, pp. 222-229, 2018, https://doi.org/10.1016/j.proeng.2018.01.029

[39] Z. E. El-awad, J. Gabrielsson, and D. Politis, "Entrepreneurial Learning and Innovation: the Critical Role of Team-level Learning for the Evolution of Innovation Capabilities in Technology-based Ventures," International Journal of Entrepreneurial Behavior \& Research Article information, no. February, 2017, https://doi.org/10.1108/IJEBR-06-2016-0177

[40] J. Fox, L. Pittaway, and I. Uzuegbunam, "Simulations in Entrepreneurship Education: Serious Games and Learning Through Play,” 2018, https://doi.org/10.1177/2515127417737285

\section{$7 \quad$ Authors}

Dr. Heny Kusdiyanti, S.Pd., M.M, is a lecturer at the Departement of Management, Faculty of Economy, Universitas Negeri Malang, Malang, Indonesia. She has over many articles in Economics Education, Learning Media, and Learning Model based on Technoology and Entrepreneurship. She is the reviewer for many kind of journal related to economic education, management, and administrative studies. Email: heny. kusdiyanti.fe@um.ac.id

Dr. Karkono, S.S., M.A, is a lecturer at the Departement of Language Education, Indonesian and Regional Literature, Faculty of Literature, Universitas Negeri Malang, Malang, Indonesia. He has done many research in Indonesian and Regional Literare, Learning Media Development. He is the judge in many student competition related to literature studies. Email: karkono.fs@um.ac.id

Sopingi, S.Sos, M.Pd, is is a lecturer at the Departement of Non-Formal Education, Faculty of Science Education, Universitas Negeri Malang, Malang, Indonesia. $\mathrm{He}$ has done for many research in non-formal learning media, and learning model. $\mathrm{He}$ is a national reviewer for Student Creativity Program by Ministry of Education. $\mathrm{He}$ is studying at Universitas Negeri Malang to get doctoral degree. Email: sopingi.fip@, um.ac.id

Indra Febrianto, S.Pd., M.Pd, is a fresh graduate from Economics Development Departement, Faculty of Economics, Universitas Negeri Malang, Malang, Indonesia. 
$\mathrm{He}$ is a research assistance at Universitas Negeri Malang and has done many research related to economics education, regional economics, entrepreneurship, and agriculture economics. Email: indrafebrianto31@gmail.com

Robby Wijaya, S.Pd., M.Pd, is a fresh graduate from Vocational Education Departement, Faculty of Engineering, Universitas Negeri Malang, Malang, Indonesia. He is a research assistance at Universitas Negeri Malang and has done many research related to vocational education, gamification, and entrepreneurship model. Email: robbywijaya1206@gmail.com

Nur Indah Agustina, S.Pd, is a master student in Chemistry Departement, Faculty of Mathematics and Natural Sciences, Universitas Negeri Malang, Malang, Indonesia. She is a research assistance for many research related to learning media development and society empowerment. She is studying at Universitas Negeri Malang to get master degree. Email: nurindaha97@gmail.com

Article submitted 2021-12-06. Resubmitted 2022-01-10. Final acceptance 2022-01-10. Final version published as submitted by the authors. 